\title{
PERKAWINAN SIRI DALAM PERSPEKTIF HUKUM ISLAM, HUKUM POSITIF DAN HAK ASASI MANUSIA
}

\author{
Oleh: Enik Isnaini, SH, MH
}

\begin{abstract}
Abstrak
Perkawinan siri merupakan bentuk ajaran hukum islam dan jika dipandang dari hukum perkawinan yaitu Undang Undang Nomor 1 Tahun 1974, perkawinan siri merupakan bentuk perkawinan yang dilarang oleh hukum perkawinan. Namun hal ini jika dikaitkan dengan adanya hak asasi manusia, dimana perkawinan merupakan hak dasar yang dijamin oleh konstitusi maupun undang-undang maka perkawinan siri sah-sah saja. Oleh Karena itu masalah perkawinan sirri merupakan konflik norma yaitu norma hukum islam, hukum perkawinan dan hak asasi manusia. Sehingga keberadaan kawin sirri yang berkembang di masyarakat terdapat pro dan kontra.

Perkawinan sirri termasuk kategori perkawinan yang dilakukan dibawah tangan, yang mana menurut ketentuan Hukum Islam adalah sah, sedangkan secara hukum dapat dikatakan tidak sah (batal) atau dapat dibatalkan. Untuk mendapatkan status Hukum perkawinan sirri dengan jalan mengisbatkan dahulu (mengesahkan) akan perkawinannya di Pengadilan Agama. Bagi orang-orang yang melaksanakan perkawinan sirri dapat dikenakan Peraturan Pemerintah Nomor 9 Tahun 1975 pasal 45, yang dikenakan aturan ini bukan karena pelaksanan dari perkawinan itu tetapi karena pelanggarannya.

Perkawinan sirri apabila dilihat dari perspektif hak asasi manusia tidak bertentangan dengan hukum karena masalah perkawinan merupakan hak dasar bagi manusia yang merupakan anugerah dari Tuhan dan itu telah diatur dalam konstitusi (UUD 1945) maupun dalam Undang Undang Nomor 39 Tahun 1999 tentang hak asasi manusia. Namun demikian masalah perkawinan sirri saat ini masih diperbincangkan atau diperdebatkan oleh ulama', praktisi hukum maupun para pemegang kekuasaan negara yang kaitannya dengan sanksi hukum perkawinan sirri. Dalam perkawinan sirri akan berakibat hukum terhadap staus anak/staus social maupun terhadap harta kekayaan perkawinan dan disamping itu perkawinan siri tersebut tidak menjamin adanya kepastian hukum baik bagi suami isteri maupun bagi anak-anaknya serta dapat menimbulkan anggapananggapan negatif dalam lingkungan masyarakat.
\end{abstract}

\section{Kata Kunci : Perkawinan Sirih, Perspektif Hukum Islam, Hukum Positif, HAM}

\section{A. Pendahuluan}

\section{Latar Belakang Masalah}

Manusia diciptakan oleh Allah SWT sebagai khalifah dimuka bumi ini diperintahkan mengolah, mengatur dan memakmurkan bumi ini. Di samping hal itu Allah juga menjadikan manusia untuk berpasang-pasangan dimuka bumi ini agar antara satu orang dengan orang yang lain saling mengenal dans saling bertolongtolongan, karena manusia mempunyai naluri ingin mempertahankan hidupnya, maka keinginan untuk berketurunan selalu timbul pada dirinya. Untuk melaksanakan hal tersebut jalan satu-satunya yang harus ditempuh yaitu dengan jalan melaksanakan suatu perkawinan. Dengan adanya perkawinan tentunya diperlukan suatu Undang-undang yang mengatur adanya suatu perkawinan. Dan hal ini baru terwujud sejak diberlakukannya Undang- undang Nomor I tahun 1974 tentang perkawinan. Berarti bangsa Indonesia telah mempunyai satu sistem hukum perkawinan yang bersifat nasional yang diberlakukan bagi seluruh bangsa Indonesia sendiri. Tepatnya pada tanggal 2 Januari 1974 disahkan dan diundangkannya undang-undang Republik Indonesia Nomor I tahun 1974 yaitu tentang perkawinan.

Amandemen Undang-Undang

Dasar 1945 mengatur secara luas mengenai hak asasi manusia bahkan menempatkan masalah hak asasi manusia dalam bab tersendiri, hal tersebut membuktikan betapa pentingnya mengenai hak asasi manusia karena pada dasarnya hak asasi manusia merupakan hak dasar yang dianugerahkan oleh Tuhan Yang Maha Esa. Sebagai implementasi mengenai hak asasi manusia yang telah diatur dalam Undang Undang Dasr 1945 tersebut, Pemerintah telah 
mengesahkan Undang-Undang nomor 39 tahun 1999 tentang hak asasi manusia. Perkawinan merupakan salah satu hak asasi manusia, baik yang diatur dalam hukum islam maupun dalam konstitusi. Perkawinan siri merupakan bentuk ajaran hukum islam dan jika dipandang dari hukum perkawinan yaitu Undang Undang Nomor 1 Tahun 1974, perkawinan siri merupakan bentuk perkawinan yang dilarang oleh hukum perkawinan. Namun hal ini jika dikaitkan dengan adanya hak asasi manusia, dimana perkawinan merupakan hak dasar yang dijamin oleh konstitusi maupun undangundang maka perkawinan siri sah-sah saja. Oleh Karena itu masalah perkawinan sirri merupakan konflik norma yaitu norma hukum islam, hukum perkawinan dan hak asasi manusia. Sehingga keberadaan kawin sirri yang berkembang di masyarakat terdapat pro dan kontra.

Adapun yang menjadi faktor penyebabnya antara lain:

1. Adanya tindakan untuk menyelamatkan masing-masing dari perbuatan zina.

2. Kurang fahamnya sebagian anggota masyarakat terhadap Undang-Undang No. 1 Tahun 1974 tentang Perkawinan.

3. Adanya keberanian sebagian masyarakat yang disegani atau ditokohkan untuk menikahkan tanpa sepengetahuan pihak yang berwenang.

\section{Perumusan Masalah}

Berdasarkan atas latar belakang
masalah tersebut diatas penulis mengemukakan beberapa permasalahan sebagai berikut:

1. Bagaimana perspektif perkawinan sirri menurut Hukum Islam dan Undang Undang Nomor 1 Tahun 1974 serta dilihar dari Hak Asasi Manusia?

2. Bagaimana akibat hukum dari perkawinan sirri?

\section{Tujuan Penelitian}

Adapun tujuan dari penulisan Tesis ini adalah:

1. Untuk mengetahui bagaimana perspektif perkawinan sirri menurut Hukum Islam dan Undang Undang Nomor 1 Tahun 1974 serta dilihar dari perspektif Hak Asasi Manusia.

2. Untuk mengetahui bagaimana akibat hukum dari perkawinan sirri.

\section{B. Kajian Teori}

Pengertian Dan Tujuan Perkawinan

Dalam kehidupan manusia di dunia ini. Yang berlainan jenis kelaminnya (lakilaki dan perempuan) secara alamiha mempunyai daya tarik-menarik antara satu dengan yang lainnya untuk dapat hidup bersama, atau secara logis dapat dikatakan untuk membentuk suatau keluarga/rumah tangga yang rukun, bahagia, sejahtera dan abadi.

Hal ini bukanlaah merupakan sesuatu keharusan, agar orang berpendapat atau menitik beratkan kepada persetubuhan belaka, walaupun hal ini persetubuhan adalah faktor yang juga penting sebagai penunjang atau pendorong dalam rangka merealisir hidup bersama, baik untuk mendapatkan keturunan/anak, maupun sekedar memenuhi kebutuhan biologis atau keinginan hawa nafsu belaka, karena dapat juga pula terjadi, bahwa hidup bersama antara manusia yang berlainan jenis kelaminnya tadi dilakukan tanpa persetubuhan, walaupun hal ini merupakan suatu pengecualian.

Sesorang yang hidup bersama, kekuatan untuk bersetubuh bukanlah merupakan suatu syarat yang tidak boleh tidak harus ada, karena hal ini tidaklah selalu terdapat pada semua golongan orang, seperti misalnya orang yang sudah lanjut usianya. Hal ini terbukti pada kenyataan, seperti yang dikemukakan oleh Dr. R. Wirjono Proodikoro, S.H :

"Bahwa diperbolehkan suatu perkawinan antara dua orang yang sudah sangat lanjut usia, bahkan diperbolehkan pula suatu perkawinan dinamakan 'Inextrimes' yaitu pada waktu salah satu pihak sudah hampir meninggal dunia. ${ }^{1}$

Masalah perkawinan bukan hanya sekedar memenuhi kebutuhan biologis dan kehendak manusia tetapi lebih dari itu, yaitu suatu ikatan atau hubungan lahir batin antara seorang pria dan seorang wanita. 
Perkawianan merupakan suatau ikatan yang sah untuk membina rumah tangga dan keluarga sejahtera bahagia dimana kedua suami istri memikul amanah dan tanggung jawab, si istri oleh karenanya akan mengalami suatau proses psikologis yang berat yaitu kehamilan dan melahirkan yang meminta pengorbanan. ${ }^{2}$

Bagaimana juga suatu perkawinan yang sukses tidak dapat diharapkan dari mereka yang masih kurang matang, baik fisik maupun mental emosional, melainkan menuntut kedewasaan dan tanggung jawab serta kematangan fisik dan mental. Untuk itu suatu perkawinan haruslah dimasuki dengan suatu persiapan yang matang.

Perkawinan yang mengandalkan kekuatan cinta tanpa disertai dengan persiapan yang matang untuk melanjutkan penelusuran kehidupan, akan mengalami banyak kelemahan apalagi kalau cinta yang bertolak dari pemikiran sederhana dan terjajah oleh dominasi emosional. Jadi untuk memasuki perkawinan bukan hanya cinta saja yang dibutuhkan melainkan pemikiran yang rasional dan dapat meletakkan dasardasar lebih kokoh dari suatu perkawinan, sedangkan perkawinan itu sendiri merupakna suatu proses awal dari perwujudan bentukbentuk kehidupan manusia.

Undang-undang Republik Indonesia Nomor 1 tahun 1974 tentang perkawinan, dalam pasal 1 yang berbunyi : Perkawinan ialah ikatan lahir batin antara seorang pria dengan seorang wanita sebagai suami istri dengan tujuan membentuk keluarga (rumah tangga) yang bahagia dan kekal berdasar ketuhanan yang maha Esa. Dari bunyi pasal 1 undang-undang nomor 1 tahun 1974 tersebut diatas, tersimpul suatu rumusan arti dan tujuan dari perkawinan.

"Arti perkawinan" dimaksud adalah : ikatan lahir batin antara seorang pria dengan seorang wanita sebagai suami istri, sedangkan "Tujuan" perkawinan yang dimaksud adalah: membentuk keluarga (rumah tangga) yang bahagia dan kekal berdasarkan ketuhanan yang maha Esa.

${ }^{2}$ Majalah Nasehat Perkawinan No. 109 ke X Juni 1981 Penerbit Badan Penasehat Perkawinan Perselisihan dan Perceraian (BP4), hal. 14.
Indonesia sebagai negara yang berdasarkan Pancasila yang sila pertamanya ialah ketuhanan yang maha Esa, maka antara perkawinan dan agama atau kerohanian mempunyai hubungan yang sangat erat, karena perkawinan bukan saja mempunyai unsur jasmani tetapi juga mempunyai unsur rohani yang memegang peranan penting.

Pengertian perkawinan seperti yang tercantum dalam Undang-undang Perkawinan Nomor 1 tahun 1974 pasal 1, bila diperinci yaitu :

a. Perkawinan ialah ikatan lahir batin antara seorang pria dengan seorang wanita sebagai suami isteri;

b. Ikatan lahir batin ditujukan untuk membentuk keluarga (rumah tangga) yang bahagia, kekal dan sejahtera;

c. Ikatan lahir batin dan tujuan bahagia yang kekal itu berdasarkan pada ketuhanan yang maha Esa.

Tujuan perkawinan yang diinginkan dalam undang-undang nomor 1 tahun 1974, bila kita rasakan adalah sangat ideal. Karena tujuan perkawinan itu tidak hanya melihat dari segi lahirnya saja tetapi sekaligus terdapat adanya suatu pertautan batin antara suami istri yang ditujukan untuk membina suatu keluarga atau rumah tangga yang kekal dan bahagia bagi keduanya dan sesuai dengan kehendak Tuhan Yang Maha Esa.

Dalam perkawinan "Ikatan Lahir batin" dimaksud, adalah lahir saja, atau ikatan batin saja. Akan tetapi ikatan lahir saja, atau ikatan batin saja, akan tetapi ikatan lahir dan ikatan batin yang merupakan pondasi yang kuat dalam membentuk dan membina keluarga yang bahagia yang kekal.

Selanjutnya, tujuan prekawinan adalah untuk membentuk rumah tangga atau keluarga yang bahagia dan kekal. Hal ini dimaksudkan bahwa perkawinan itu hendaklah berlangsung seumur hidup dan tidak boleh berakhir begitu saja. Dan pembentukan keluarga yang bahagia dan kekal itu, haruslah berdasarkan ketuhanan Yang Maha Esa, sebagai azas pertama dalam pancasila.

Dalam hukum perdata, hubungan antara suami istri hanya melihat dari segi lahirnya saja atau dari segi hubungan pardata, artinya yaitu terlepas dari peraturan perturan yang diadakan oleh suatu agama tertentu . 
Selanjutnya, perkawinan menurut agama islam adalah sebagai berikut :

Perkawinan adalah sunah nabi, oleh karena itu bagi pengikut yang baik, mereka itu harus kawin. Selain mencontoh tindak laku nabi muhamad, perkawinan itu juga merupakan kehendak rohani dan jasmani.

Perkawinan itu disyariatkan sejak dahulu kala, ini dikemukaan juga oleh $\mathrm{H}$. Arsosastro Atmojo, S.H. yaitu : Perkawinan itu disyariatkan sejak dahulu supaya manusia mempuntyai keturunan dan keluarga yang sah menuju kehidupan bahagia di dunia dan di akhirat, dibawah naungan cinta dan ridho Allah. ${ }^{3}$ Perkawinan yang disyariatkan itu hanya diatur dalam kitab suci Al-Quran misalnya mengenai perkawinan yang dilakukan oleh seorang pria terhadap seorang wanita yang menjadi pilihannya.

\section{Pengertian Kawin Siri}

Dengan adanya suatu perkawinan yang digunakan sebagai dasar yuridisnya yaitu firman Allah SWT yang terdapat dalam surat An-Nisa ayat 3 dan Surat An-Nuur ayat 32 yang artinya sebagai berikut ini:

Arti Surat An-Nisa ayat 3:

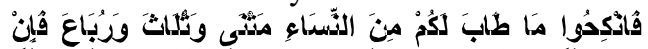

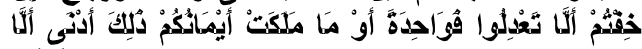

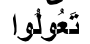

Artinya:

"Nikahilah oleh kalian wanita-wanita (lain) yang kalian senangi: dua, tiga, atau empat. Kemudian jika kamu khawatir tidak akan dapat berlaku adil, maka (nikahilah) seorang saja, atau budak-budak yang kalian miliki (Qs. An-nisa' : 3)".

Arti Surat An-Nuur ayat 32:

"Dan kawinlah orang-orang yang sendirian diantara kamu dan orang-orang yang layak berkawin dari hamba-hamba sahayamu yang perempuan. Jika mereka miskin Allah akan memampukan mereka dengan karunia-Nya. Dan Allah Maha Luas (pemberian-Nya) lagi Maha Mengetahui. " (An-Nuur ayat 32)

Sedangkan dasar pengertian yang mempunyai sifat pokok kiranya perlu untuk dikemukakan terlebih dahulu yang mana akan penulis gunakan sebagai landasan dasar atau sebagai titik tolak dalam

${ }^{3}$ Arso Sastroatmodjo, Hukum Perkawinan, Bulan Bintang, 1978, hal. 3. pengupasan dan pembahasan materi dalam tesis ini lebih lanjut. Disamping itu pengertian dasar akan perkawinan sirri itu berguna juga sebagai pedoman yang memberikan gambaran tentang inti permasalahan yang akan penulis uraikan dan bahas lebih mendetail dalam bab-bab selanjutnya. Pemberian akan gambaran dari inti permasalahan tersebut sangat perlu agar dalam uraian materi selanjutnya tidak menyimpang jauh dari permasalahan yang penulis tetapkan.

Apabila dipandang sepintas lalu saja, maka suatu perkawinan adalah merupakan suatu persetujuan saja dalam masyarakat antara seorang laki-laki dan seorang perempuan seperti persetujuan antara orang satu dan orang lain dalam hal sewa menyewa, jual beli, tukar menukar dan lain sebagainya, tetapi tidaklah demikian halnya di dalam persetujuan-persetujuan biasa, setiap pihak yang mengadakan persetujuan berhak untuk menentukan sendiri apa yang dijanjikan dari orang-orang yang mengadakan persetujuannya semuanya sendiri, asalkan semua yang dijanjikan itu tidak bertentangan dengan Undang-Undang dan ketertiban umum, maupun kesusilaan.

Dalam suatu perkawinan sudah sejak semula ditentukan oleh umum, isi dari suatu persetujuan antara seoarng laki-laki dan perempuan untuk menjadi suami istri dan membentuk keluarga bahagia. Sehingga perkawinan itu haruslah berlangsung seumur hidup dan tidak boleh diputuskan begitu saja, terkecuali itu karena adanya suatu kematian diantara kedua belah pihak atau dikarenakan adanya suatu perceraian sebagai langkah akhir apabila jalan lain tidak dapat ditempuh lagi.

Apabila seorang laki-laki maupun seorang perempuan mengadakan suatu kesepakatan untuk melaksankan suatu perkawinan satu sama lain, berarti mereka sudah berjanji untuk mentaati semua peraturan hukum yang berlaku baik itu mengenai hak-hak dan kewajibankewajiban istrinya selama dan sesudah hidup bersama itu berlangsung dan juga memperhatikan akan kedudukan anak-anak turunanya dalam masyarakat. Juga dalam penghentian perkawinan atau bercerai diantara suami dan istri tidak bisa seenaknya saja menentukan sendiri 
beberapa syarat-syarat untuk menghentikan itu, melainkan terikat juga pada peraturan hukum perihal itu.

Diatas telah dinyatakan bahwa pengertian akan perkawinan tidaklah dapat dipandang lepas dari hukum perkawinan yang berlaku didalam suatu negara, maka hak yang demikian ini tidaklah berarti bahwa sifat keseluruhan dari suatu perkawinan dapat terlihat kesemuanya dimana peraturan akan hukum itu. Sebarnya peraturan hukum perkawinan itu hanya meliputi pokok-pokoknya saja dari suatu persoalan yang timbul dalam hidup bersama yang dinamakan perkawinan, yang lebih penting dalam peraturan hukum itu ialah "praktek" yang didalam suatu negara tertentu dilakukan oleh suami dan istri selama hidup bersama itu. Dan praktek ini ada hubungannya yang erat dengan alam perasaan dan dengan alam pikiran suatu bangsa maupun suku bangsa akan persoalan-persoalan kesusilan. Adalah mungkin apabila praktek ini berlainan dan menyimpang dari hukum perkawinan (peraturan hukum perkawinan) yang berlaku. Kalau praktek yang berlainan ini terbatas pada dua atau tiga orang saja, maka tidaklah perlu hal yang demikian ini diperhatikan. Sudah sewajarnyalah apabila dalam suatu masyarakat selalu ada beberapa orang yang tidak mentaati akan suatu peraturan hukum itu, sebaliknya kalau praktek itu dilakukan oleh sebagian besar masyarakat, maka sudah sepatutnyalah untuk dipikirkan. Sehingga dengan terjadinya suatu perkawinan yang dilaksanakannya hanya melalui proses agama saja, dan tidak melalui proses hukum (tidak dicatatkan pada Pejabat yang berwenang). Maka bentuk perkawinan yang demikian inilah yang sering diistilahkan dengan suatu "Perkawinan Sirri".

Perkawinan Sirri yaitu: suatu perkawinan yang dilakukan oleh orang-orang Islam Indonesia, memenuhi baik rukun-rukun maupun syarat-syarat perkawinan, tetapi tidak didaftarkan pada pejabat Pencatat Nikah, seperti diatur dan ditentukan oleh Undang-
Undang Nomor 1 tahun 1974 tentang Perkawinan. ${ }^{4}$

Memang kalau dilihat sepintas saja masalah perkawinan Sirri ini merupakan suatu persoalan yang tidak begitu besar. Meskipun begitu perkawinan Sirri ini sangat luas akan obyek yang ditimbulkannya yang meliputi seluruh aspek kehidupan dalam masyarakat. Dalam hal ini sangatlah perlu untuk dibuktikan kebenarannya baik dari pandangan Undang-undang yang sedang berlaku di negara kita sekarang ini maupun dari pandangan Hukum Islam yang berdasarkan Al-Qur'an dan Hadist. Adanya suatu anggapan yang menyatakan dengan diberlakunanya Undang-Undang Perkawinan, Hukum Perkawinan tidak berlaku lagi adalah kurang tepat, sebab menurut ketentuan pasal 66 Undang-Undang Perkawinan Nomor 1 Tahun 1974 yang dinyatakan tidak berlaku lagi bukanlah peraturan-peraturan secara keseluruhan, melainkan hanyalah hal-hal yang mengatur perkawinan sejauh telah diatur dalam Undang-Undang Perkawinan. Sedangkan hal-hal yang tidak diatur' dalam Undang-Undang Perkawinan dinyatakan masih tetap berlakunya Hukum Perkawinan Islam bagi orang-orang yang memeluk agama Islam hal ini dengan tegas diatur dalam pasal 2 ayat 1 Undang-Undang Perkawinan yang menentukan bahwa, perkawinan adalah sah apabila dilakukan masing-masing hukum agamanya dan kepercayaan, maka dengan demikian segala hal yang belum diatur dan tidak bertentangan dengan undang-undang perkawinan ini, masih tetap berlaku menurut hukum masing-masing agamanya dan kepercayaannya. Oleh karena itu apabila warga negara Indonesia yang beragama Islam yang hendak melakukan perkawinan agar sah harus dilakukan menurut ketentuan Hukum Perkawinan Islam.

\section{Syarat dan Sahnya Perkawinan Menurut Undang-Undang No. 1 tahun 1974}

Berdasarkan ketentuan pasal 2 ayat 1 UU Nomor 1 Tahun 1974, suatu perkawinan dianggap sah apabila dilakukan menurut

\footnotetext{
${ }^{4}$ Majalah Hukum dan Pembangunan, 1982.

Terbitan bulan Nopember. h. 54.
} 
hukum agamanya dan kepercayaannya masing-masing. Didalam ayat 2 disebutkan tiap-tiap perkawinan dicatat menurut peraturan perundang-undangan yang berlaku. Sehubungan dengan ketentuan pasal 2 ayat 1 tersebut maka bagi warga Negara yang beragama Islam dalam melaksanakan perkawinan yang diafur dalam hukum agama Islam. Dalam hal ini yang menjadi permasalahan atau perkawinan antara mereka yang berbeda agama, sebab pelaksanaan perkawinan bagi yang berbeda agama tidak ada ketentuan baik didalam undang-undang perkawinan maupun dalam peraturan pelaksanaannya. Dengan adanya ketentuan pasal 2 ayat 1 ini sebenarnya untuk menghindari konflik hukum antara hukum adat, hukum antar golongan, maupun antar agama. Sehingga apabila terjadi perkawinan yang berbeda agama seharusnya mereka memilih agama dan kepercayaan yang mereka peluk, tanpa menentukan sikap dan kepercayaannya lebih dahulu. Sesuai dengan ketentuan pasal 2 ayat 1 dalam perkawinan tidak mungkin sekaligus menggunakan ketentuan hukum agama dan kepercayaan sebab semua aturan agama antara yang satu dengan lainnya tentunya mempunyai perbedaan akan kaidah hukum yang mengatur tata cara syarat-syarat maupun rukun-rukun dalam suatu perkawinan. Juga mengenai sah tidaknya perkawinan ditentukan oleh hukum agama masing-masing.

Sedangkan pasal 2 ayat 2 Undang-undang Nomor 1 Tahun 1974 yang berisi tiap-tiap perkawinan dicatat menurut peraturan perundang-undangan yang berlaku. Meskipun pencatatan itu bersifat administrative saja.

Didalam bukunya K. Wantjik Saleh, SH

"Hukum perkawinan Indonesia" dikatakan bahwa:

"Sebagai salah satu perbuatan hukum, perkawinan mempunyai akibat hukum. Adanya akibat hukum penting sekali hubungannya dengan sahnya perbuatan hukum itu. Suatu perkawinan yang menurut hukum dianggap tidak sah umpamanya, maka anak yang lahir dari perkawinan itu akan merupakan anak yang tidak sah."

\footnotetext{
${ }^{5}$ K. Wantjik Saleh, op.cit. h.15.
}

Untuk sahnya perkawinan, maka haruslah memenuhi segala ketentuan undang-undang perkawinan.

Mengenai syarat-syarat perkawinan didalam Undang-undang diatur dalam pasal 6 dan pasal 7 Undang-undang Nomor 1 tahun 1974 yang pada pokoknya memuat hal-hal sebagai berikut:

1. Perkawinan harus didasarkan atas persetujuan kedua calon mempelai.

2. Harus mendapat ijin kedua orang tua bagi yang belum berumur 21 tahun.

3. Apabila salah satu orang tua meninggal dunia atau tidak mampu menyatakan kehendaknya, maka ijin ayat 2 diperoleh dari orang tua yang masih hidup atau dari orang tua yang mampu menyatakan kehendaknya.

4. Apabila kedua orang tua meninggal dunia atau tidak mampu menyatakan kehendaknya, maka yang berhak memberi ijin adalah:

- Wali yang memelihara calon mempelai

- Atau keluarga yang mempunyai hubungan darah dalam garis keturunan lurus keatas selama mereka masih hidup dalam keadaan dapat menyatakan kehendaknya.

5. Dalam hal perbedan pendapat antara orang-orang yang disebut dalam ayat 2, 3 dan 4 ini, atau salah seorang atau lebih diantara mereka tidak menyatakan pendapatnya, maka Pengadilan dalam daerah hukum tempat tinggal orang yang akan melangsungkan perkawinan atas permintaan orang tersebut dapat memberikan ijin setelah lebih dahulu mendengar orang-orang tersebut dalam ayat 2", 3 dan 4 pasal ini.

6. Ketentuan tersebut ayat 1 sampai dengan ayat 5 pasal ini berlaku sepanjang hukum masing-masing agamanya dan kepercayaannya itu dari yang bersangkutan tidak menentukan lain.

7. Batas umur perkawinan.

Penetapan batas umur perkawinan sangatlah penting, karena mutu perkawinan disamping menghendaki 
kematangan psikologis juga membutuhkan kematangan biologis.

Dalam pasal 7 ayat 1 Undang-undang Nomor 1 Tahun 1974 (Undang-undang Perkawinan) menetapkan pria harus sudah mencapai umur 19 tahun dan wanita harus sudah mencapai umur 16 tahun, baru diijinkan untuk melangsungkan perkawinan. Apabila telah mengadakan penyimpangan terhadap usia yang telah ditetapkan, dapat meminta dispensasi kepada Pengadilan atau pejabat lain yang ditunjuk oleh kedua orang tua pria maupun pihak wanita (pasal 7:2).

Ketentuan mengenai keadaan salah seorang atau kedua orang tersebut dalam pasal 6 ayat 3 dan 4 Undang-undang ini berlaku juga dalam hal permintaan dispensasi tersebut ayat 2 pasal ini dengan tidak mengurangi yang dimaksud dengan pasal 6 ayat 6 .

\section{Metode Penelitian}

\section{Tipe Penelitian}

Tipe penelitian hukum yang dilakukan adalah yuridis normatif (hukum normatif). Metode penelitian hukum normatif adalah suatu prosedur penelitian ilmiah untuk menemukan kebenaran berdasarkan logika keilmuan hukum dari sisi normatifnya. ${ }^{6}$ Oleh karena itu penelitian hukum ini difokuskan untuk mengkaji penelitian hukum tentang kaidah-kaidah atau norma-norma dalam hukum positif, yakni norma hukum yang terkait dengan perkawinan siri ditinjau dari UndangUndang Nomor 1 Tahun 1974 dan Hak Asasi Manusia.

\section{Pendekatan Masalah}

Oleh karena tipe penelitian yang digunakan adalah tipe penelitian yuridis normatif, maka pendekatan yang digunakanadalah pendekatan perundangundangan (statute approach).

Pendekatan tersebut melakukan pengkajian peraturan perundangundangan yang berhubungan dengan pokok permasalahan. Selain itu juga digunakan pendekatan konsep (conceptual approach). Pendekatan konsep ini digunakan untuk membuat konsep-konsep ketentuan-ketentuan hukum yang terkait dengan perkawinan siri ditinjau dari Undang-Undang Nomor 1 Tahun 1974 dan Hak Asasi Manusia.

\section{Bahan Hukum}

Bahan hukum yang
dipergunakan dalam penelitihan ini
adalah sebagai berikut:

a. Bahan hukum primer:

Bahan hukum primer adalah merupakan bahan hukum yang bersifat autoritatif artinya mempunyai otoritas, bahan hukum terdiri dari perundang-undangan, catatan resmi, atau risalah dalam pembuatan perundang-undangan dan putusan hakim. Adapun bahan hukum primer tersebut meliputi: Undang Undang Dasar 1945 (amandemen), UndangUndang Nomor 1 Tahun 1974 tentang perkawinan, Undang Undang Nomor 39 tahun 1999 tentang hak asasi manusia, Al Qur'an.

b. Bahan Sekunder:

Bahan hukum sekunder adalah bahan yang diperoleh dari buku teks, jurnaljurnal, pendapat para sarjana dan kasus-kasus hukum.

\section{Prosedur Pengumpulan Bahan Hukum}

Baik bahan primer maupun bahan hukum sekunder dikumpulkan berdasarkan topik permasalahan yang telah dirumuskan dan diklasifikasi menurut sumber dan hirarkinya untuk dikaji secara komprehensif.

\section{Pengolahan dan Analisis Bahan Hukum} Adapun bahan hukum yang diperoleh dalam penelitian adalah studi kepustakaan, aturan perundang-undangan, yang penulis uraikan dan dihubungkan sedemikian rupa, sehingga disajikan dalam penulisan yang lebih sistematis guna

\footnotetext{
${ }^{6}$ Johnny Ibrahim, Teori \& Metode Penelitian Hukum Normatif, Banyumedia Publishing, Malang 2005, hal..57
}

7 Peter Mahmud Marzuki. Penelitian

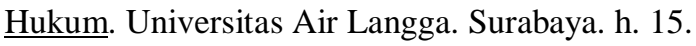


menjawab perumusan masalah yang dirumuskan. Cara pengolahan bahan hukum dilakukan secara deduktif yakni menarik kesimpulan dari suatu permasalahan yang bersifat umum terhadap permasalahan kongkrit yang dihadapi,s elanjutnya bahan hukum dianalisa untuk melihat bagaimana perkawinan siri ditinjau dari Undang-Undang Nomor 1 Tahun 1974 dan Hak Asasi Manusia,

D. Hasil Penelitian dan Pembasan

Perspektif perkawinan sirri menurut hukum islam, hukum positif dan Hak Asasi Manusia.

\section{Perkawinan Siri Menurut Hukum Islam}

Apabila dilihat dari aspek sosial, bahwa suatu perkawinan itu mempunyai arti yang penting dan teristimewa dimana hal ini telah terjadi dua orang manusia yang tadinya tidak ada hubungan apapun (merupakan orang lain), apabila terjadi suatu ikatan suami istri, sebenarnya ikatan itu tidak berhenti sampai disitu saja melainkan sampai pada hubungan famili, kerabat dan hubungan kekeluargaan. Sehingga semua agama memandang bahwa perkawinan merupakan suatu kejadian yang sangat penting dan diistimewakan.

Disamping itu banyaknya penilaian umum yang berpendapat bahwa orang yang melakukan perkawinan atau pernah melakukan perkawinan mempunyai kedudukan yang lebih dihargai daripada mereka yang belum kawin. Khususnya bagi kaum wanita dengan perkawinan akan memberikan kedudukan sosial yang tinggi, karena ia sebagai istri dan wanita mendapat hak-hak tertentu dan dapat melakukan tindakan hukum dalam berbagai lapangan mu'amalat, yang tadinya ketika masih gadis tindakantindakannya masih terbatas, harus dengan persetujuan dan pengawasan dari orang tuanya. $^{8}$
Dari pandangan masyarakat tersebut diatas inilah maka dalam suatu masyarakat masih dilakukan suatu perkawinan sirri. Dalam hal ini disamping dijumpai didesa-desa ada juga sebagian masyarakat kota yang masih melaksanakan suatu perkawinan sirri, baik yang berpendidikan tinggi maupun yang rendah.

Penulis telah mengemukakan diatas bahw suatu perkawinan sirri adalah suatu perkawinan yang dilakukan oleh orang-orang Indonesia yang beragama Islam, yang telah memenuhi baik rukunrukun maupun syarat-syarat perkawinan tetapi tidak dicatatkan pada pejabat pencatat nikah, sebagaimana yang ditentukan oleh Undang-undang Nomor 1 Tahun 1974. Dengan tidak dicatatkannya akan perkawinan sirri ini, maka suatu perkawinan itu tidak terdaftar didalam suatu akta negara. Perkawinan sirri itu merupakan bagian daripada perkawinan Islam, maka apabila mereka melakukan suatu perkawinan sirri syarat-syarat dan rukun-rukun yang harus dipenui adalah harus sesuai dengan yang ada dalam perkawinan menurut agama Islam.

\section{Perkawinan Sirri Menurut Undang- undang Nomor 1 Tahun 1974}

Terlepas dari adanya bermacammacam masyarakat dengan berbagai corak ragamnya dalam proses melaksanakan perkawinan sesuai dengan adat mereka, namun dengan dikeluarkannya Undangundang Nomor 1 Tahun 1974 tentang peraturan pelaksanaannya tidak lain adalah dimaksudkan sebagai univikasi hukum khususnya di bidang Perkawinan di Indonesia. Mengingat semakin mendesaknya tuntutan zaman dan kompleksnya permasalahan yang terjadi dengan adanya perkawinan, sehingga dalam hal ini pencatatan perkawinan sangatlah diperlukan.

Menurut ketentuan Undangundang Nomor 1 Tahun 1974 bukan merupakan perbuatan hukum saja, tetapi juga merupakan suatu perbuatan

${ }^{8}$ Ny. Soemiati. 1982. Hukum Perkawinan Islam

No.l tahun 1974 tentangperkawinan), Yogyakarta: dan Undang-undang Perkawinan (Undang-undang Liberty, h. 11. 
keagamaan. Berdasarkan ketentuan pasal 2 ayat 1 Undang-undang Perkawinan, perkawinan dianggap sah apabila dilaksanakan menurut hukum agamanya dan kepercayaannya masing-masing. Menurut penjelasan yang dimaksud dengan hukum masing-masing agamanya dan kepercayaannya itu termasuk ketentuan perundang-undangan yang berlaku bagi golongan agamanya dan kepercayaan itu sepanjang tidak bertentangan/tidak ditentukan lain dalam undang-undang ini. Sehingga oleh karenanya sah atau tidaknya suatu perkawinan digantungkan sepenuhnya pada masing-masing hukum agama dan kepercayaan yang dianut oleh masyarakat Indonesia. Dengan demikian sahnya suatu perkawinan tidak tergantung dengan adanya pencatatan perkawinan melainkan untuk menentukan sah tidaknya perkawinan yang diadakan itu ditentukan hukum agamanya masingmasing. Mengenai pencatatan perkawinan seperti yang tersebut pada pasal 2 ayat 2 Undang-undang Perkawinan, dalam hal ini hanyalah sebagai kegiatan administratif yang tidak mempengaruhi terhadap sahnya suatu perkawinan.

Didalam masa pluralisme hukum perkawinan sebelum ditetapkannya Undang-undang Perkawinan yang sekrang perbedaan yang demikian sangatlah terlihat sekali, dimana untuk satu golongan penduduk misal yang tunduk pada $\mathrm{BW}$ (Kitab Undang-undang Hukum Perdata), hanya mengakui bahwa suatu perkawinan itu hanyalah suatu perbuatan keperdataan saja yang menganggap bahwa acara-acara keagamaan yang dianut oleh para mempelai hanya formalitas belaka sehingga suatu larangan terhadap seorang pejabat agama untuk melaksanakan perkawinan sebelum prosedur keperdataanya di penuhi. Hal ini berdasarkan pasal 26 BW yang menyatakan bahwa, undang-undang memandang suatu persoalan dalam perkawinan hanya dalam hubungan keperdataan saja. Bagi golongan yang beragama islarn sekalipun tidak secara tegas mengakui perkawinan hanya dalam hubungan keperdataan saja. Bagi golongan yang beragama Islam sekalipun tidak secara tegas mengakui perkawinan tetap dipandang sebagai suatu perbuatan keagamaan yang prosedurnya dan mengenai tata caranya harus dilaksanakan menurut Hukum Islam. Untuk sahnya suatu perkawinan yang ditinjau dari sudut keperdataan belaka sebelum perkawinan tersebut sudah dicatat atau didaftar pada Kantor Catatan Sipil, selama perkawinan itu belum terdaftar perkawinan tersebut masih belum dianggap sah menurut ketentuan hokum sekalipun mereka sudah memenuhi prosedur dan tata cara menurut ketentuan agama, sehingga dari itu adanya kemungkinan timbulnya apa yang disebut " Anak haram Perdata" disamping istilah anak haram menurut ketentuan hukum Islam, atau menurut ketentuan hukum agama.

\section{Perkawinan Sirri Dalam Perspektif Hak Asasi Manusia}

Rancangan Undang-Undang (RUU) Hukum Materiil Peradilan Agama Bidang Perkawinan yang akan memidanakan pernikahan tanpa dokumen resmi atau nikah siri memicu kontroversi.

Ketua Umum Pengurus Besar Nahdlatul Ulama (PBNU) KH Hasyim Muzadi menilai pemidanaan nikah siri sebagai langkah tidak benar. "Saya kira ini tidak benar. Nikah siri cukup diadministrasikan saja. Harusnya yang lebih dulu dipidanakan itu yang tidak nikah (berhubungan seks di luar nikah). Saya yakin ini ada agenda tersembunyi untuk melegalkan yang melakukan seks bebas (free sex) dan menyalahkan yang nikah,"kata Hasyim kepada harian Seputar Indonesia (SI) di Gedung PBNU Jakarta kemarin. Pemerintah sejauh ini bersikukuh memperjuangkan draf RUU yang sudah masuk Program Legislasi Nasional (Prolegnas).

Menteri Hukum dan Hak Asasi Manusia (Menkum HAM) Patrialis Akbar menegaskan, nikah siri perlu diatur agar ada kepastian hukum dalam pernikahan dan kepastian hukum anakanak mereka. "Jadi yang bagus kan nikah itu ada suratnya. Jadi jangan hanya, maaf ya, dalam tanda kutip, lakilaki itu jangan sekadar make aja dong.Tanggung 
jawabnya di mana dong? Lahir batin dong! Kanitu bagian dari perkawinan, jadi dia harus bertanggung jawab. Kalau punya anak, anaknya jadi tanggung jawabnya," ujar Patrialis Akbar di selasela kunjungan ke LP Anak Kelas II A Tangerang mendampingi Presiden Susilo Bambang Yudhoyono kemarin. Untuk diketahui, draf usulan RUU Hukum Materiil Peradilan Agama Bidang Perkawinan menampung pasal tentang nikah siri atau nikah yang tidak tercatat di kantor urusan agama (KUA). Pasal tersebut menyebutkan, jika seseorang melakukan nikah siri atau melakukan kawin kontrak,ia dapat diancam dengan pidana penjara.

Pasal 143 RUU UU yang hanya diperuntukkan bagi pemeluk Islam ini menggariskan, setiap orang yang dengan sengaja melangsungkan perkawinan tidak di hadapan pejabat pencatat nikah dipidana dengan ancaman hukuman bervariasi, mulai dari enam bulan hingga tiga tahun dan denda mulai dari Rp6 juta hingga Rp12 juta. Selain kawin siri,draf RUU juga menyinggung kawin mutah atau kawin kontrak.

Pasal 144 menyebut, setiap orang yang melakukan perkawinan mutah dihukum penjara selamalamanya 3 tahun dan perkawinannya batal karena hukum. RUU itu juga mengatur soal perkawinan campur (antardua orang yang berbeda kewarganegaraan). Pasal 142 ayat 3 menyebutkan, calon suami yang berkewarga negaraan asing harus membayar uang jaminan kepada calon istri melalui bank syariah sebesar Rp500 juta.

Menurut Patrialias,masyarakat harus diberi kesadaran bahwa nikah itu tidak sekadar nikah atau bohong-bohongan. Menurutnya, banyaknya pria menikah di bawah tangan dan janda-janda muda menjadi stimulasi agar hal tersebut perlu diatur. Ditegaskan, pengaturan pernikahan bukan berarti negara ikut campur dalam masalah agama. "Kalau kehidupan bermasyarakat tidak diatur,masyarakat bisa kacau. Ya, kalau kehidupan beragama itu misalnya begini, orang mengaji harus mengaji dari jam sekian sampai sekian, itu baru namanya ikut campur,"jelasnya.

Di tempat sama, Menteri Agama Suryadharma Ali menuturkan bahwa draf RUU tersebut sudah dibuat sekitar lima tahun lalu atau sebelum dirinya menjabat sebagai Menteri Agama. Karena itu, pembahasan mengenai nikah siri akan kembali dilihat pasal demi pasal oleh fraksi-fraksi yang ada di DPR.

Dari daftar inventarisasi masalah yang telah masuk itu,akan muncul berbagai pandangan mengenai rancangan pasal itu."Mungkin saja ada yang cocok atau kurang cocok, mungkin nanti bertemu, pemikiran yang lebih sesuai dari apa yang dikonsepkan sekarang,"ujarnya. Ketua Umum DPP Partai Persatuan Pembangunan (PPP) ini mengakui, nikah siri dalam syariah agama disahkan. Namun dalam peraturan undang-undang hal itu tidak bisa disahkan karena belum tercatat dalam administrasi negara. Untuk itu, Suryadharma meminta para pelaku nikah siri untuk segera mencatatkan perkawinannya ke KUA."Mereka harus mencatatkan itu (pernikahannya ke KUA), bukan berarti nikahnya nggak sah. Bila tidak sah kan berarti berzina bertahun-tahun,"katanya. Dirjen Bimas Islam Kementerian Agama Nasarudin Umar menjelaskan, maksud draf RUU tersebut tiada lain hanya untuk menjadikan kewibawaan perkawinan terjaga karena dalam Islam perkawinan adalah hal yang suci.

Selain itu, RUU ini diajukan terkait masalah kemanusiaan. Dia berharap, adanya UU ini nantinya akan mempermudah anak mendapatkan haknya seperti dapat warisan, hak perwalian, pembuatan KTP, paspor,serta tunjangan kesehatan dan sebagainya.

Ketua Mahkamah Konstitusi Mahfud MD menyatakan dukungannya terhadap draf RUU Hukum Materiil Peradilan Agama Bidang Perkawinan.Dalam pandangannya, nikah siri itu lebih banyak merugikan anakanak dan kaum perempuan. "Anak-anak yang lahir dari kawin siri itu tidak diakui hukum dan tidak mendapatkan hak waris," jelasnya di Gedung MK kemarin. 
Mahfud menyatakan,perempuan yang dinikahi secara siri tidak diakui oleh hukum sehingga jika seseorang mempunyai dua istri, kemudian istri pertama adalah hasil pernikahan yang tercatat dan istri kedua adalah hasil nikah siri,maka istri pertama sangat kuat di hadapan hukum. "Jika istri pertama mengatakan saya istri yang sah,maka hal itu tidak bisa dilawan dengan hukum, "jelasnya.Kendati demikian, dia menggariskan bahwa RUU tersebut perlu didiskusikan.

Ketua Umum Fatayat NU Maria Ulfa Anshor juga mendukung langkah pemerintah mengatur kawin siri. Secara tegas dia menyatakan kawin siri dan kawin kontrak sangat berisiko bagi perempuan untuk menjadi korban. Dia menolak pendapat yang menyebut pengaturan itu melanggar HAM walaupun perkawinan merupakan isu privat. "Penegakan HAM bukan berarti semua hal yang terkait dengan persoalan privat tidak ada aturannya. Negara mengatur dalam rangka memberikan koridor. Nikah siri bias berdampak timbulnya ketidakadilan bagi perempuan,"katanya.

Wakil Ketua Lembaga Bahtsul Masail Nahdlatul Ulama (LBMNU) Arwani Faishal mengingatkan bahwa pernikahan adalah masalah perdata. Karena itu akan menjadi kezaliman pemerintah jika memenjarakan pelakunya. Dia kemudian membandingkan dengan pelaku kumpul kebo yang jelasjelas bertentangan dengan agama mana pun, tapi tidak pernah dikenai sangsi pidana oleh negara. "Lho, orang-orang yang menjalankan ajaran agama justru diancam dengan hukuman penjara? Jika ini terjadi justru negara malah bertindak zalim,"kata Arwani. Menurutnya, pernikahan siri atau pernikahan yang tidak didaftarkan secara administratif kepada negara adalah perkara perdata yang tidak tepat jika diancam dengan hukuman penjara. Bahkan sanksi material (denda) juga tetap memiliki dampak sangat buruk bagi masyarakat.

"Bila mengenakan denda dalam jumlah tertentu untuk orangorang yang melakukan nikah siri, tentu hal ini dapat menimbulkan ketidakadilan. Bukan masalah bagi mereka yang punya uang banyak. Namun tidak adil bagi mereka yang secara ekonomi hidupnya paspasan,"kata Arwani. Dalam pandangannya, nikah siri memiliki berbagai dampak positif (maslahah) dan dampak negative (mafsadah) yang samasama besar.

Jika dilegalkan, akan sangat rawan disalahgunakan dan jika tidak diakui akan bertentangan dengan syariat Islam. "Untuk itu dampak negatif dan positif pernikahan siri harus dikaji dan disikapi bersama,"katanya. (nurul huda/kholil/ rarasati syarief)

\section{Akibat Hukum Status anak}

1. Akibat Hukum Harta Kekayaan Perkawinan

Dengan adanya ikatan sebuah perkawinan, sebagaimana telah disebutkan-diatas menurut Undang Undang Nomor 1 Tahun 1974, bahwa perkawinan adalah adanya ikatan lahir dan batin yang bertujuan untuk membentuk sebuah keluarga yang bahagia dan kekal berdasarkan Ketuhanan Yang Maha Esa. Kebahagiaan dan kekalnya sebuah keluarga tidak menutup kemugkinan dengan terpenuhinya segala kebutuhan. Baik secara kebutuhan lahir maupun kebutuhan batin atau dari segi nuterial maupun spiritual. Dengan terpenuhinya segala kebutuhan materi juga harus diimbangi dengan terpenuhinya kebutuhan spiritual, kedua hal ini harus tercipta dalam sebuah rumah tangga. Biasanya kebutuhan materi menjadi persoalan yang paling penting dalam keluarga, tanpa didukung dengan terpenuhinya kebutuhan materi ini akan menjadi sebuah kendala dalam menciptakan keharmonisan keluarga.

Persoalan pembagian atau kedudukan harta dalam perkawinan, sering kali muncul apabila terjadi konflik dalam keluaga itu sendiri, baik persolan harta warisan, harta bersama atau yang disebut dengan 
Gono - Gini, Hibah dan lainnya. Harta kekayaan perkawinan meliputi benda bergerak ataupun benda tak bergerak dan surat - surat berharga. Sebenarnya persoalan harta benda dalam perkawinan sudah diatur dalam Undang - Undang Nomor 1 Tahun 1974 pasal 35 ayat 1 dan 2, yang mengatakan bahwa :

"1. Harta benda yang diperoleh selama perkawinan menjadi harta bersama.

2. Harta bawaan dari masing masing suami dan isteri dan harta benda yang diperoleh masing-masing sebagai hadiah atau warisan, adalah dibawah penguasaan masing-.masing sepanjang para pihak tidak menetukan lain".

Dari uraian pada Undang-undang diatas adalah jelas, bahwa harta benda yang diperoleh selama adanya ikatan perkawinan adalah menjadi harta bersama, sedangkan harla bawaan dari masin-masing suami isteri dan harta benda vang diperoleh oleh masing-masing sebagai hadiah atau warisan adalah dibawah penguasaan masing-masing suami isteri. Masing-masing suami isteri mempunyai hak sepenuhnya untuk melakukan perbuatan Hukum mengenai harta bendanya. Apabila terjadi perselisihan sehingga menyebakan keretakan dalam perkawinan, misalnya perkawinan putus karena perceraian ataupun karena kematian maka penyelesaiannya dapat diajukan di Pengadilan.

Hal inilah yang menjadi sebuah persoalan, bilamana perkawinannya akibat dari perkawinan Siri. Tentunya mereka ticiak bisa menyelesaikan persoalan harta benda dalam perkawinan mereka dimuka pengadilan. Karena pengadilan menganggap perkawinan yang mereka lakukan tidak pernah ada, dengan tidak adanya bukti secera tertulis yaitu Akta Nikah yang dibuat oleh pegawai pencatat Nikah.
Terus bagaimana status dari hak waris, dari anak yang dilahirkan dari perkawinan siri? karena status perkawinan yang dilakukan dari perkawinan tidak diakui oleh Undung-undang, maka secara tidak langsung anak yang dilahirkan dari akibat perkawinan Siri statusnya tidak sah, karena anak yang sah adalah anak yang dilahirkan dari akibat atau dalam perkawinan yang sah. Hal ini sesuai dengan bunyi pasal 42 Undang - undang Nomor 1 tahun 1974 bahwa :

"Anak yang sah adalah anak yang dilahirkan dalam atau sebagai akibat perkawinan yang sah"

Dengan demikian dia dianggap sebagai anak yang dilahirkan diluar perkawinan yang sah. Bagi anak yang dilahirkan dari hasil diluar perkawinan, dia hanya memiliki hubungan perdata dengan ibunya dan keluarga ibunya. Dengan demikian dia hanya bisa mendapatkan hak waris hanya dari ibu dan saudara ibunya. Bisa mendapatkan haknya, berupa harta atau benda dari Ayahnya tetapi bukan waris hanya bersifat hadiah atau hibah. Secara perdata seorang ayah tidak memiliki hubungan perdata dengan anaknya, karena dilahirkan diluar pernikahan yang sesuai dengan Undang -Undang.

Dengan demikian bahwa persoalan-persoalan yang muncul dalam rumah tangga yang ditimbulkan dari akibat perkawinan Siri, dengan jelas tidak dapat diselesaikan di depan Pengadilan kearena, dari hasil perkawinan mereka tidak memeiliki kekuatan Hukum yang tetap dengan adanya Akta Nikah sehingga pernikahan yang dikkukan dianggap tidak pernah ada. 


\section{E. Penutup}

\section{Kesimpulan}

Dari semua uraian tersebut diats dapatlah ditarik suatu kesimpulan sebagai berikut:

1. Bahwa menurut Undang-undang Nomor 1 Tahun 1974 tentang perkawinan beserta Peraturan Pelaksanaannya tidak bertentangan dengan hukum Islam, tidak boleh dikatakan telah membawa pandangan secara kongkrit dari ketentuan hukum Islam bahkan telah dianggap merupakan sumber hukum baru yang harus dipatuhi sepanjang sumber hukum baru yang harus dipatuhi sepanjang mengenai syaratsyarat sahnya nikah.

Perkawinan sirri termasuk kategori perkawinan yang dilakukan dibawah tangan, yang mana menurut ketentuan Hukum Islam adalah sah, sedangkan secara hukum dapat dikatakan tidak sah (batal) atau dapat dibatalkan. Untuk mendapatkan status Hukum perkawinan sirri dengan jalan mengisbatkan dahulu (mengesahkan) akan perkawinannya di Pengadilan Agama. Bagi orang-orang yang melaksanakan perkawinan sirri dapat dikenakan Peraturan Pemerintah Nomor 9 Tahun 1975 pasal 45, yang dikenakan aturan ini bukan karena pelaksanan dari perkawinan itu tetapi karena pelanggarannya.

Juga perkawinan sirri apabila dilihat dari perspektif hak asasi manusia tidak bertentangan dengan hukum karena masalah perkawinan merupakan hak dasar bagi manusia yang merupakan anugerah dari Tuhan dan itu telah diatur dalam konstitusi (UUD 1945) maupun dalam Undang Undang Nomor 39 Tahun 1999 tentang hak asasi manusia. Namun demikian masalah perkawinan sirri saat ini masih diperbincangkan atau diperdebatkan oleh ulama', praktisi hukum maupun para pemegang kekuasaan negara yang kaitannya dengan sanksi hukum perkawinan sirri.

2. Dalam perkawinan sirri akan berakibat hukum terhadap staus anak/staus social maupun terhadap harta kekayaan perkawinan dan disamping itu perkawinan siri tersebut tidak menjamin adanya kepastian hukum baik bagi suami isteri maupun bagi anak-anaknya serta dapat menimbulkan anggapan-anggapan negatif dalam lingkungan masyarakat.

\section{Saran}

Akhirnya untuk mengakhiri penyusunan Tesis ini adanya harapan dari penulis agar:

1. Mengharap kepada masyarakat Indonesia pada umumnya dan masyarakat Indonesia yang beragama Islam pada khususnya agar dalam melaksanakan perkawinan mengikuti cara pengaturan yang tercantum dalam Undang- undang Nomor 1 Tahun 1974 dan peraturan pelaksanaannya secara konsekuen, sebab Undang-undang tersebut adalah ciptaan bangsa Indonesia pada tanggal 2 Januari 1974, dan tentunya sudah disesuaikan dengan keadaan dan kondisi dari bangsa Indonesia itu sendiri.

2. Bagi Pejabat Pengadilan Agama dan Pejabat Kantor Urusan Agama sering kali diadakan penyuluhan akan Undangundang Nomor 1 Tahun 1974 kepada baik masyarakat di desa-desa maupun kepada generasi muda agar mereka mengetahui isi dari pada Undang-undang Nomor 1 Tahun 1974.

\section{DAFTAR PUSTAKA}

\section{LITERATUR:}

ArsoSastroatmodjo, BulanBintang, 1978

HukumPerkawinan,

Johnny Ibrahim,

Teori\&MetodePenelitianHukumNormatif

, Banyumedia Publishing, Malang 2005

K. WantjikSaleh. HukumPerkawinan

Indonesia.Jakarta, 1976, Ghalis Indonesia

MajalahNasehatPerkawinan No. 109 ke X Juni 1981

PenerbitBadanPenasehatPerkawinanPers elisihandanPerceraian (BP4)

MajalahHukumdan Pembangunan, 1982.TerbitanbulanNopember. 
Peter Mahmud Marzuki. PenelitianHukum. Universitas Air Langga. Surabaya.

Ny. Soemiati. 1982. HukumPerkawinan Islam danUndang-undangPerkawinan (Undang-undangNo.ltahun 1974 tentangperkawinan), Yogyakarta: Liberty

R. WirjonoProjodikoro, HukumPerkawianan di Indonesia,Sumur Bandung Jakarta, Jakarta, 1984

PERUNDANG-UNDANGAN:

UndangUndangDasar 1945

Undang-UndangNomor 1 Tahun 1974

tentangPerkawinan

UndangUndangNomor 39 Tahun 1999

tentangHakAsasiManusia 